\title{
EFFECT OF PREBIOTICS ON LYZOSYMIC ACTIVITY OF THE BACILLUS GENUS BACTERIA
}

\author{
M.A. SAVEKA, O.A. VASYLCHENKO \\ National Aviation University, Kiev
}

Beneficial effects on a host health of probiotic strains of spore-forming bacteria of the Bacillus genus in combination with prebiotic substance lactulose were investigated. The influence of prebiotic lactulose on the Bacillus subtilis 39 and Bacillus subtilis 51 lyzosymic activity were analyzed. The dependence of the growth inhibition zones extension on lactulose quantity introduced into cultural medium was displayed.

Key words: probiotics, prebiotics, synbiotics, lyzosymic activity, lactulose, Bacillus subtilis, Micrococcus luteus, growth inhibition zones

\section{Introduction}

Probiotics are viable cell preparations that have beneficial effects on the health of a host by intestinal balance amendment via improved feed value, enzymatic contribution to digestion, inhibition of pathogenic microorganisms, antimutagenic and anticarcinogenic activities, growth-promoting factors and an increased immune response [1].

Probiotic preparations are becoming increasingly available to the public as beneficial functional foods that purport to promote health benefits of consumers. They are used in bacterioprophylaxis of gastrointestinal disorders in humans. Often these disorders are a direct result of antibiotic usage, which creates an imbalance in the normal intestinal microbiota composition. Bacteria most commonly used as probiotics include the lactic acid bacteria (LAB), e.g. lactobacilli, enterococci, 
streptococci, and bifidobacteria. Probiotic preparations may be ineffective in term of fail to deliver the proper number of bacteria to the place of their main action, i.e. colon. But probiotic preparations that combine various probiotic bacteria with oligosaccharide substrates (prebiotics) get more popularity.

Nowadays the problem of finding effective, safe and economically beneficial probiotic strains of bacteria as well as in combination with prebiotics for creation of more potent drug is ongoing researches. Two strains of spore-forming aerobes as B. subtilis in combination with lactulose or lactitol can be used as effective probiotics for solving all these problems, because of its effective potential transition through the stomach to the colon, high antagonistic activity against pathogenic microorganisms and opportunistic pathogens of gastrointestinal tract [2], comparatively low cost of their cultivation and rapid action.

Experimental evidences suggest that the ingestions of substantial numbers of harmless bacteria indeed provide a beneficial effect on the enteric biota. Except for the lactic acid bacteria, Bacillus species are also used as probiotics [1-3]. Probiotic preparations contain bacterial spores, with the potential advantage that the spore can survive during transition through the stomach intact. Bacillus species are substantially different from other probiotic bacteria, being primarily aerobic saprophytes found in the soil. It's also known that some Bacillus species belong to transient normal microbiota of human gastrointestinal tract, thus, can be easily used as probiotics [2, 3].

Prebiotic effect of lactulose was proved in multiple investigations by increased bifidobacteria number in the colon of patients [4]. Lactulose stimulates the growth of normal bowel human microbiota, promotes infection resistance of the organism against a range of pathogenic microorganisms and opportunistic pathogens such as Shigella, Salmonella, Rotavirus, Yersinia etc [5]. The earlier scientific investigations showed the possibility of successful combinations of probiotic bacteria with prebiotic lactulose $[6,7]$.

It's essential to determine lyzosymic activity of B. subtilis 39 and Bacillus subtilis 51 during their co-cultivation with lactulose and prebiotic influence on the enzyme activity. Lyzosymic activity of the strain plays a main role in pathogenic 
microrganisms and opportunistic pathogens growth inhibition, thus probiotic efficacy elevation.

\section{Materials and methods}

Lyzosymic activity of two B. subtilis strains at their cultivation with prebiotic lactulose was examined. For lyzosymic activity (LA) determination molten and cooled to temperature $45^{\circ} \mathrm{C}$ meat-peptonic agar (MPA) nutrient medium was used. MPA was poured in monotonic layer in a Petri plates. After nutrient medium solidification and cooling one drop of broth with daily test cultures prepared according turbidity standard number 10 was inoculated. Inocula were incubated for $18-24$ hours at temperature $37^{\circ} \mathrm{C}$. After incubation living cells of microorganisms were being treated with chloroform fumes for $30 \mathrm{~min}$. After chloroform treatment, nutrient medium with $0.2 \mathrm{ml}$ of 1 billion daily agar suspension of Micrococcus luteus culture were poured on macrocolonies. The results of the experiment were counted after the day of incubation at temperature $37^{\circ} \mathrm{C}$. Growth inhibition zones (GIZ) of M. luteus indicator culture were observed around lyzosyme-active cultures. Quantitative evaluation of LA was detected at maximum concentration of lyzosyme in the plates with inhibited indicator culture.

\section{Results and discussions}

Lyzosyme is an enzyme that belongs to a class of hydrolases. It selectively hydrolyzes glycosidic bonds in murein - complex biopolymer, which is the part of the bacterial cell wall [8].

As a result of conducted experiments, it's found that the probiotic strain B. subtilis 39 has a quite expressed lyzosymic activity (GIZ $=15 \pm 1 \mathrm{~mm})$ in contrast to $B$. subtilis 51 (GIZ = $1 \pm 0,3 \mathrm{~mm}$ ) (Fig. 1). With prebiotic lactulose addition into the cultural medium lyzosymic activity significantly increases, at the same time enzymatic activity depends on the concentration of lactulose in the medium. 


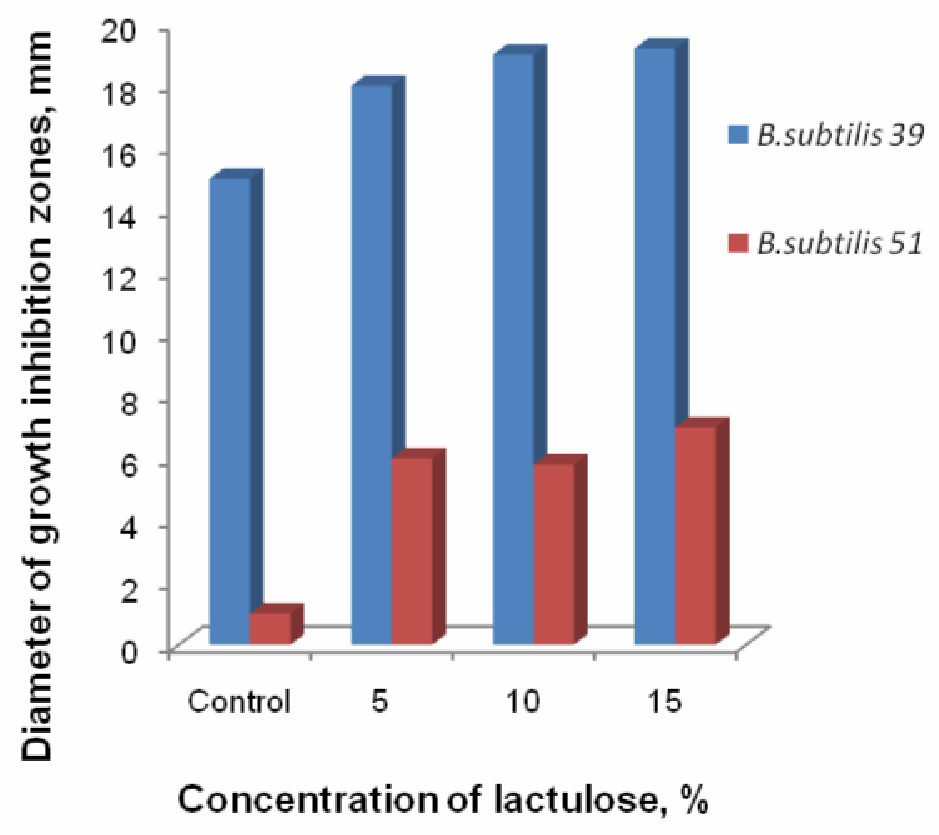

Fig.1. Lactulose effect on bacilli probiotic strains lyzosymic activity

Lyzosymic activity increasing was also observed with $P$. aeruginosa 4141 . The initial GIZ diameter of test-culture M. luteus $5 \pm 1,2 \mathrm{~mm}$, lactulose addition into the cultural medium changes the enzymatic activity that depends on prebiotic concentration in the medium $(\mathrm{GIZ}=8 \pm 1,5 \mathrm{~mm})$.

\section{CONCLUSIONS}

Provided investigations clearly show that lactulose adding into the nutrient medium results in a increased lyzosyme biosynthesis by strains B. subtilis 39 and B. subtilis 51. Prebiotic addition significantly elevates antagonistic activity of bacilli against pathogens, amplifying the useful qualities of probiotic preparation. Thus, lactulose can be successfully applied together with both B. subtilis strains in a new combined synbiotic product. Also this study gives essential impulse for the further investigations of several probiotic bacteria strains combination with different nature prebiotics for finding the most efficient and economically profitable one that may significantly amplify the useful qualities of chosen probiotic bacteria strains. 


\section{REFERENCES}

1. Casula G. Bacillus probiotics: spore germination in the gastrointestinal tract / G. Casula, S.M. Cutting // Applied And Environ. Microbiology. - 2002. - Vol. 68. P. $2344-2352$.

2. Green D.H. Characterization of Two Bacillus Probiotics / D.H. Green, P.H. Wakeley, A. Page // Applied And Environ. Microbiology. - 1999. - Vol.65, № 9. - P. $4288-4291$.

3. Hoa N.T. Characterization of Bacillus Species Used for Oral Bacteriotherapy and Bacterioprophylaxis of Gastrointestinal Disorders / N.T. Hoa, L. Baccigalupi, A. Huxham // Applied And Environ. Microbiology. - 2000. - Vol.66, № 12. P. 5241- 5247.

4. Clausen M.R. Lactulose, disaccharides and colonic flora. Clinical consequences / M.R. Clausen, P.B. Mortensen // Drugs. - 1997. - Vol.53. - P.930 942.

5. De Preter V. Lactulose administration in healthy volunteers is associated with a reduced beta-glucuronidase activity and an increase in fecal bifidobacteria / V. De Preter, H. Raemen, T. Vanhoutte // Gut. - 2005. - Vol.54. - P. 17.

6. Saveka M.A. Influence of Prebiotics Lactitol and Lactulose on the Growth of Probiotic Strains Bacillus subtilis 39 and Bacillus Subtilis 51 and the Growth of Opportunistic Pathogens / M.A. Saveka, M.A. Charchota, O.A. Vasylchenko / Materials of the III International Research and Practice Conference ["Current problems of Biology, Ecology and Chemistry"], (Zaporizhzhya, May 11-13 ${ }^{\text {th }}, 2012$ ). - Zaporizhzhya: Copy Art, 2012. - P. 368 - 369.

7. Charalampopoulos D. Prebiotics and Probiotics Science and Technology / D. Charalampopoulos, R. A. Rastall- New York, NY, USA: Springer, 2009. - 1273 p.

8. Lederberg J. Encyclopedia of Microbiology / J. Lederberg - [ 2nd ed]. Vol. 1. - New York, USA: Academic Press, 2000. - P. 1896-1907. 


\title{
ВПЛИВ ПРЕБІОТИКІВ НА ЛІЗОЦИМНУ АКТИВНІСТЬ БАКТЕРІЙ РОДУ ВАCILLUS
}

\author{
М. А. Савека, О. А. Васильченко \\ Наиіональний авіаиійний університет, м. Київ
}

Досліджено позитивний вплив на здоров'я організму-господаря пробіотичних штамів спороутворюючих бактерій роду Bacillus у поєднанні 3 пребіотиком лактулозою. Проаналізовано вплив лактулози на лізочимну активність пробіотичних итамів Bacillus subtilis 39 ma Bacillus subtilis 51. Показано залежність збільшення діаметру зон пригнічення росту патогенних та умовно-патогенних мікроорганізмів від кількості лактулози, внесеної у поживне середовище.

Ключові слова: пробіотики, пребіотики, синбіотики, лізочимна активність, лактулоза, Bacillus subtilis, Micrococcus luteus, зони пригнічення pocmy.

\section{ВЛИЯНИЕ ПРЕБИОТИКОВ НА ЛИЗОЦИМНУЮ АКТИВНОСТЬ БАКТЕРИЙ РОДА ВАСILLUS}

\author{
М.А. Савека, О.А. Васильченко \\ Национальный авиационный университет, г. Киев
}

\begin{abstract}
Исследовано положительное влияние на здоровье организма-хозяина пробиотических итаммов спорообразующих бактерий рода Bacillus 6 комбиначии с пребиотиком лактулозой. Проанализировано влияние лактулозы на лизоцимную активность пробиотических штаммов Bacillus subtilis 39 и Bacillus subtilis 51. Показана зависимость увеличения диаметра зон
\end{abstract}


угнетенного роста патогенных и условно-патогенных микроорганизмов от количества лактулозы, внесённой в питательную среду.

Ключевые слова: пробиотики, пребиотики, синбиотики, лизочимная активность, лактулоза, Bacillus subtilis, Micrococcus luteus, зоны угнетенного pocma. 